\title{
Hubungan Kadar Vitamin D pada Ibu Hamil dengan Berat Bayi Lahir di Kabupaten Tanah Datar dan Kabupaten Solok
}

\author{
Nidya Ikha Putri ${ }^{1}$, Nur Indrawaty Lipoeto ${ }^{2}$, Rauza Sukma Rita ${ }^{3}$, Arif Sabta $\mathrm{Aji}^{4}$ \\ Pendidikan IImu Biomedik Pascasarjana Fakultas Kedokteran Universitas Andalas ${ }^{1}$ \\ Bagian Gizi Fakultas Kedokteran Universitas Andalas ${ }^{2}$ \\ Bagian Biokimia Fakultas Kedokteran Universitas Andalas ${ }^{3}$ \\ Pendidikan Ilmu Biomedik Master Fakultas Kedokteran Universitas Andalas ${ }^{4}$ \\ e-mail: nidyaikhap@gmail.com
}

\begin{abstract}
The main cause of infant mortality is Low Birth Weight (LBW). Basd on data obtained from the West Sumatra Provincial Health Office in 2015, from 1376 case of 92.444 babies weighed, and there were 2,066 (2.2\%) LBW in 2014. Growth and development of the fetus need vitamin $D$ for cell and bone growth. The design of this study is cross sectional and conducted in Tanah Datar District in the working area of Puskesmas Simabur, Puskesmas Lima Kaum I, and in Puskesmas Lima Kaum II and Solok District in the working area of Puskesmas Talang, Puskesmas Gaek Jua and Puskesmas Tanjung Bingkung from January 2017 to March 2018. The study population was third trimester pregnant women with a population of 60 respondents, by multistage random sampling. Examination of vitamin D levels by ELISA method. Data were analyzed by univariate and bivariate with normality test. The result of this study that level are the average vitamin D content of $25.44 \pm 10.49 \mathrm{pg} / \mathrm{ml}$ and the median weight of the baby born is 3000 gram. There was a positive relationship between vitamin $D$ levels in pregnant women with birth weight $(r=0,463),(p<0,05)$. The conclusion of this research is that there is a significant association between vitamin $D$ levels in pregnant women with infants born weight in West Sumatra.
\end{abstract}

Keywords:

The Vitamin D, Infant Birth Weight.

\section{PENDAHULUAN}

Salah satu penanda asupan gizi ibu selama kehamilan dapat dilihat dari berat bayi lahir. Tingginya angka kematian bayi khususnya pada masa perinatal yang dikarenakan oleh berat bayi lahir rendah (BBLR) merupakan masalah yang banyak terjadi pada Asia Selatan sebesar $28 \%$,

Asia Timur dan Pasifik hanya 6\%, Amerika Latin 9\%, serta Afirka 13\% (WHO, 2014). Data Riskesdas tahun 2013 menyatakan bahwa persentase balita (0-59 bulan) dengan BBLR sebesar $10,2 \%$, terjadi penurunan jika dibandingkan dengan hasil Riskesdas 2010 sebesar $11,1 \%$. Prevalensi BBLR tertinggi terdapat di Provinsi Sulawesi Tengah (16,8\%) dan terendah di Sumatera Utara $(7,2 \%)$, serta Sumatera Barat sekitar 7,8\% (Kemenkes, 2014).

Berdasarkan data yang diperoleh dari Dinas Kesehatan Provinsi Sumatera Barat tahun 2015, diketahui angka Berat Badan Lahir Rendah (BBLR) adalah 1376, bayi baru lahir ditimbang sebanyak 92.444 , dan terdapat 2.066 $(2,2 \%)$ BBLR pada tahun 2014. Jumlah BBLR tahun 2012 yang dilaporkan di Kabupaten Tanah Datar sebanyak 156 bayi, dan pada tahun 2013 bayi BBLR sebanyak 173 bayi $(3,2 \%)$ dari bayi lahir yang ditimbang (Profil Kesehatan Kabupaten Tanah Datar, 2014).

Status gizi saat kehamilan mempengarhi berat bayi lahir. Kekurangan gizi yang terjadi selama kehamilan dapat berdampak buruk pada status gizi janin yang direpresentasikan oleh berat badan lahir yang tidak optimal. Berbagai penelitian yang selama ini menggunakan 2.500 gram sebagai batas berat badan lahir dihubungkan dengan risiko morbiditas dan mortalitas bayi yang dilahirkan. Penelitian lain menunjukkan berat badan lahir di bawah 3.000 gram memiliki risiko penyakit degeneratif ketika dewasa (WHO,2006).

Berat bayi lahir dipengaruhi oleh berbagai faktor, salah satunya adalah faktor ibu. Status gizi ibu saat terjadi konsepsi dan proses kehamilan hingga kelahiran berhubungan denganberat bayi lahir. Gizi yang cukup bagi ibu dan janin sangat dibutuhkan untuk memenuhi kecukupan gizi selama kehamilan (Departemen Kesehatan RI, 2014).

Kebutuhan gizi ibu hamil berupa makromineral dan mikromineral yang harus dicukupi selama kehamilan. Salah satu kebutuhan mikromineral yang dibutuhkan ibu selama hamil adalah vitamin D. Vitamin D yang tidak tercukupi dengan baik, meningkatkan risiko terjadinya preeklampsia, diabetes gestasional, persalinan prematur, hambatan pertumbuhan janin, abortus spontan, serta berat bayi lahir rendah (Flood, et al, 2015). Kekurangan vitamin D selama kehamilan berkaitan dengan gangguan metabolisme kalsium pada janin, yaitu berupa hipokalsemia pada bayi baru lahir, hipoplasia email gigi bayi, dan osteomalasia pada ibu. Untuk menghindari hal- hal tersebut pada ibu hamil diberikan $10 \mu \mathrm{g}$ (4000 IU) vitamin D per hari selama kehamilan serta mengkonsumsi susu yang kaya vitamin D (Arisman, 2008). 
Statistik terbaru menunjukkan bahwa lebih dari $90 \%$ populasi berpigmen Amerika Serikat (kulit hitam, Hispanik, dan Asia) saat ini menderita kekurangan vitamin D (25Hidroksivitamin D $30 \mathrm{ng} / \mathrm{ml}$ ), dengan hampir tiga perempat populasi kulit putih di negara ini juga. Kekurangan vitamin $D$ ini menunjukkan hampir dua kali lipat prevalensi insufisiensi vitamin $D$ yang terlihat baru 10 tahun yang lalu pada populasi yang sama, Adams(2010).

Beberapa penelitian mengenai kadar vitamin D pada ibu Hamil memperoleh hasil yang bertolak belakang, seperti hasil penelitian Brown 2012, menyatakan bahwa pada trimester kedua, tidak ada hubungan antara kadar vitamin $25(\mathrm{OH}) \mathrm{D}$ dengan janin yang mengalami hambatan dalam pertumbuhan. Berdasarkan data diatas, maka penulis tertarik melakukan penelitian yang berjudul kadar vitamin $\mathrm{D}$ pada ibu hamil dengan berat bayi lahir. Namun berbeda dengan penelitian yang dilakukan oleh Fallahi et al, (2016), menyatakan bahwa tidak ada hubunga yang signifikan antara usia kehamilan dengan kadar vitamin $\mathrm{D}$, untuk penelitian lebih lanjut diperlukan identifikasi hubungan kelahiran premature dengan kadar vitamin $\mathrm{D}$.

\section{METODE PENELITIAN}

Desain penelitian yang digunakan adalah cross sectional, penelitian di lakukan di Kabupaten Tanah Datar yakni wilayah kerja Puskesmas Simabur, wilayah kerja Puskesmas Lima Kaum I, dan wilayah kerja puskesmas Lima Kaum II, dan Kabupaten Solok, yakni pada wilayah kerja Puskesmas Talang, wilayah kerja Puskesmas Jua Gaek, wilayah kerja Puskesmas Tanjung Bingkung Laboratorium Biomedik Fakultas Kedokteran Universitas Andalas dengan pendekatan analitik. Populasi penelitian ini semua ibu hamil dengan usia kehamilan lebih 28 minggu. Pengambilan sampel dalam penelitian ini ibu hamil yang memenuhi kriteria inklusi dan eksklusi dengan jumlah 60 responden. Kriteria inklsi antara lain, ibu hamil dengan usia kehamilan $\geq 28$ minggu, usia ibu hamil 20 tahun smapai 35 tahun, jarak kehamilan >2 tahun, serta bersedia menjadi responden.

Variabel independen dalam penelitian ini adalah kadar vitamin D pada ibu hamil, sedangkan variabel dependen berat bayi lahir.

Pengambilan darah ibu menggunakan jarum suntik disposible melalui vena mediana cubiti.Sebelum dilakukan pemeriksaan, darah yang telah diambil dimasukkan dalam tabung sentrifuge dengan kecepatan $3000 \mathrm{rpm}$ dan didiamkan selama 15 menit hingga membeku.Sampel darah diberi kode, selanjutnya dikirim ke laboratorium Biomedik untuk pemeriksaan kadar $25(\mathrm{OH}) \mathrm{D}$ menggunakan alat Human 25(OH) D ELISA KIT.
Setelah hasil kadar vitamin D didapatkan maka ibu hamil yang telah diambil darahnya, ditunggu hingga melahirkan untuk mengetahui berapa berat lahir bayinya. Penimbangan berat bayi lahir dilakukan oleh tenaga kesehatan sebelum satu jam setelah kelahiran penelitian ini Penelitian ini telah lolos kaji etik dari Komite Etika Penelitian Fakultas Kedokteran Universitas Andalas.

\section{HASIL DAN PEMBAHASAN}

Tabel 1. Distribusi responden berdasarkan umur ibu, berat badan ibu hamil, tinggi ibu hamil

\begin{tabular}{|c|c|c|}
\hline Karakteristik Responden & Mean \pm SD & Min-Max \\
\hline Umur & $27,67 \pm 4,062$ & $20-35$ \\
\hline Berat Badan Ibu Hamil TM III & $63,18 \pm 10,37$ & $37,5-93$ \\
\hline Tinggi Ibu Hamil & $153,99 \pm 5,11$ & $142-164$ \\
\hline
\end{tabular}

Dari tabel 1 dapat dilihat, rata-rata responden berumur 27 tahun dengan usia minimal 20 tahun, dan usia maksimal 35 tahun. Berat badan ibu hamil trimester III dengan ratarata 63,18 dengan berat minimal ibu $37,5 \mathrm{~kg}$ dan berat ibu maksimal $93 \mathrm{~kg}$. Rata-rata tinggi badan ibu hamil 153,99 dengan tinggi maksimal ibu 164 $\mathrm{cm}$ dan tinggi minimal ibu $142 \mathrm{~cm}$.

Tabel 2. Status Vitamin D lbu Hamil Trimester III

\begin{tabular}{ccc} 
Status Vit D & $\mathbf{N}$ & $\%$ \\
\hline Sufisiensi & 19 & 31,67 \\
Insufisiensi & 20 & 33,33 \\
Defisiensi & 21 & 35 \\
Jumlah & $\mathbf{6 0}$ & $\mathbf{1 0 0}$
\end{tabular}

Dari tabel 2 diketahui sampel status vitamin $\mathrm{D}$ ibu hamil trimester III yang mengalami defisiensi sebesar $35 \%$, dan mengalami insufisiensi sebesar $33,33 \%$, serta 19 sampel mengalami sufisiensi dengan $31,67 \%$.

Tabel 3. Rerata Kadar Vitamin D pada Ibu Hamil Trimester III

\begin{tabular}{ccc}
\hline Variabel & Mean \pm SD & Min-Max \\
\hline Kadar & $25,44 \pm 10,49$ & $8,48-60,49$ \\
$\begin{array}{c}\text { Vitamin D } \\
(\mathrm{ng} / \mathrm{ml})\end{array}$ & \\
\hline
\end{tabular}

Berdasarkan tabel 3 , dapat dilihat nilai rata-rata kadar vitamin $\mathrm{D}$ pada ibu hamil adalah $25,44 \mathrm{ng} / \mathrm{ml}$ dengan standar deviasi 10,49 $\mathrm{ng}$.

Tabel 4. Rerata Berat Bayi Lahir

\begin{tabular}{ccc}
\hline Variabel & Mean \pm SD & Min-Max \\
\hline $\begin{array}{c}\text { Berat Bayi Lahir } \\
\text { (gram) }\end{array}$ & $3066,67 \pm 328,15$ & $2200-4000$ \\
\hline
\end{tabular}




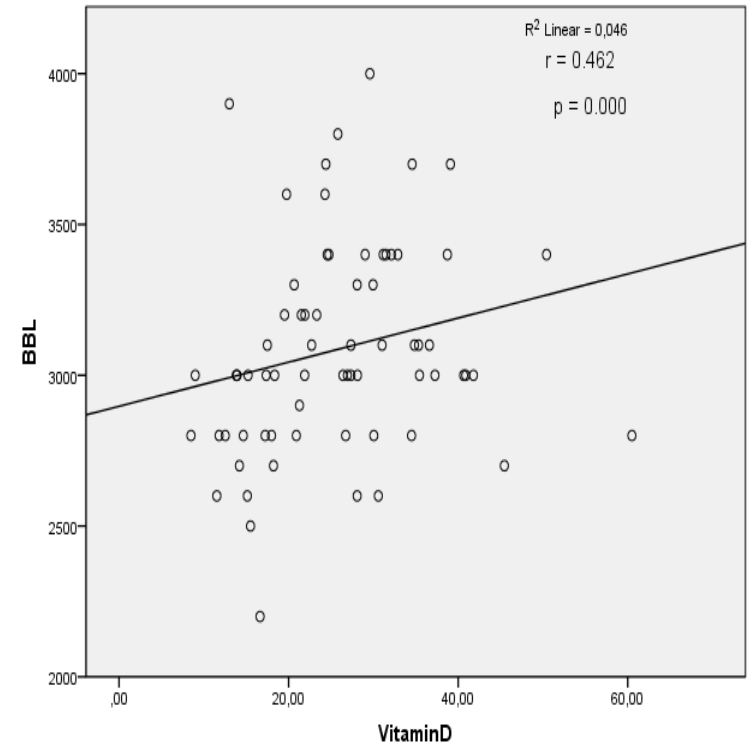

Gambar 1.

Scatter Plot Hubungan Kadar Vitamin D pada Ibu Hamil dengan Berat Bayi Lahir di Kabupaten Tanah Datar dan Kabupaten Solok

Berdasarkan gambar diatas dapat diketahui bahwa ada hubungan yang bermakna antara kadar vitamin $\mathrm{D}$ pada ibu hamil dengan berat bayi lahir(nilai $p=0,000$ ). Analisis data menunjukkan bahwa arah hubungan positif artinya semakin tinggi kadar vitamin $D$ pada ibu hamil, maka semakin berat badan bayi lahir, dimana kekuatan hubungan sedang $(r=0,462)$. Didapatkan juga dari gambar diatas bahwasanya nilai $r^{2}=0,0462$ yang artinya vitamin $D$ mempengaruhi berat bayi lahir dipengaruhi oleh faktor lainnya.

Analisis diawali dengan uji normalitas untuk mengetahui apakah data berdistribusi normal. Pada penelitian ini digunakan uji normalitas dengan kolmogorov smirnov. Data dikatakan berdistribusi normal apabila nilai $p$ $>0,05$. Jika data normal, maka dilakukan uji kolerasi Pearson. Apabila data tidak dimanipulasi statistik terlebih dahulu, dilengkapi dengan grafik, kemudian uji korelasi spearman.

Berdasarkan hasil penelitian ini, kadar vitamin D ibu hamil trimester III rata-rata 25,44 $\mathrm{ng} / \mathrm{ml}$ dengan standar deviasi $10,49 \mathrm{ng} / \mathrm{ml}$. Kadar vitamin D minimal sebesar $8,48 \mathrm{Ng} / \mathrm{ml}$, dan kadar vitamin D maksimal sebesar 60,49 $\mathrm{ng} / \mathrm{ml}$. Hasil peneltian ini dapat dilihat kadar vitamin D pada ibu hamil trimester III, 31,67\% mengalami sufisiensi, 33,33\% ibu mengalami insufisiensi, dan 35\% ibu mengalami defisiensi.

Hasil penelitian ini juga ditemukan rendahnya kadar vitamin $D$ pada ibu hamil trimester III sebesar 35\%. Hasil ini berbanding terbalik dengan penelitian Keumala (2013) didapatkan 94,9\% wanita dengan kadar 25 hidroksi vitamin D rendah. Kekurangan kadar vitamin $D$ pada ibu hamil pada daerah tropis seperti Indonesia khususnya di Sumatera Barat daerah kabupaten Tanah Datar dan kabupaten Solok dipengaruhi oleh faktor seperti gaya hidup ibu, kurangnya konsumsi makanan dan suplemen yang mengandung vitamin D Berdasarkan penelitian ini diketahui sebanyak 53,33\% berat bayi lahir dari kisaran 2500 gram hingga 3000 gram. Hasil berbeda di tunjukkan dari penelitian Rufaridah (2012) menunjukkan $37,2 \%$ berat bayi lahir BBLR. Perbedaan hasil berat badan lahir pada penelitian ini kemungkinan disebabkan oleh tidak dikumpulkannya data tentang kenaikan berat badan ibu selama hamil. Kenaikan berat badan ibu selama hamil merupakan salah satu penilaian status gizi ibu. Status gizi baik pada ibu hamil dapat mempengaruhi berat bayi lahir.

Sukma (2015) dengan responden yang sama yaitu masih rendahnya rata-rata konsumsi vitamin D pada ibu hamil trimester III sebesar 734,74 IU (normal 400-4000 IU).

Hasil analisis statistik menunjukkan bahwa ada hubungan yang bermakna $p=0,000$ $(p<0,05)$ antara kadar vitamin $D$ dengan berat bayi lahir dengan kekuatan yang sedang ( $r=$ $0,46)$ dan arah hubungan positif, yaitu semakin tinggi kadar vitamin $D$ pada ibu hamil trimester III, maka semakin besar berat bayi lahir.

Menurut (Vitrianingsih, Kusharisupeni, dan Luknis, 2012) berat bayi lahir dipengaruhi oleh faktor internal dan eksternal. Faktor internal berupa umur ibu, jarak kehamilan, paritas, kadar $\mathrm{Hb}$, status gizi ibu hamil, penyakit saat kehamilan, dan komplikasi selama kehamilan. Faktor eksternal seperti lingkungan pekerjaan ibu, tingkat pendidikan ibu, pengetahuan gizi, sosial dan ekonomi keluarga.

Penelitian yang dilakukan oleh (Hollis et al, 2011) menyatakan bahwa ibu hamil sebaiknya mengkonsumsi suplemen vitamin D dimulai dari usia kehamilan 12 minggu ,dengan dosis 400, 2000, dan 4000 IU setiap hari. Vitamin $D$ selain diperoleh dari suplemen juga dapat diperoleh dari makanan seperti kuning telur, minyak ikan, hati dan mentega serta juga dapat diperoleh dari sinar matahari.

Menurut Khalessi et al(2015), kekurangan vitamin $D$ pada ibu hamil dapat meningkatkan risiko neonatus berat lahir rendah dengan memodifikasi konsumsi ibu dalam pemenuhan nutrisi untuk meningkatkan kadar vitamin D bermanfaat untuk meningkatkan berat lahir neonatus. Dari penelitian yang dilakukan selama satu tahun, diperoleh hasil rata-rata kadar serum vit $D$ ibu di semua 102 ibu dengan usia rata-rata 26,20 tahun dan usia kehamilan rata-rata 38 minggu, adalah 31 sampai $46 \mathrm{nmol} / \mathrm{L}$ (4,3- 94 $\mathrm{nmol} / \mathrm{L})$.

Penelitian Satish (2016), terdapat prevalensi defisiensi vitamin $D$ yang tinggi pada wanita hamil India selatan dan mereka bayi yang baru lahir. Kekurangan vitamin D meningkatkan risiko neonatus berat lahir rendah dan juga 
berpengaruh pada panjang bayi, lingkar kepala dan lingkar dada.

\section{SIMPULAN}

Perlunya pengetahuan ibu hamil tentang pentingnya vitamin $D$ selama kehamilan, serta diharapkan ibu hamil memenuhi kebutuhan vitamin $D$ yang cukup agar ibu tidak mengalami defisiensi vitamin $D$ dalam membantu kerja kalsium pada ibu hamil trimester III, sehingga kecukupan vitamin $\mathrm{D}$ dapat membantu kenaikan berat bayi lahir di Kabupaten Tanah Datar dan Kabupaten Solok. Sumber vitamin D diperoleh dari paparan sinar matahari, daging merah, hati, serta kuning telur.

\section{DAFTAR PUSTAKA}

Adamova Z, Ozkan S, Khalil RA. (2009). Vascular and Cellular Calcium in Normal and Hypertensive Pregnancy. Current Clinical Pharmacology. (4). 172-190

Adams JS, Hewison M. (2010). Update in Vitamin D. J Clin Endocrinol Metab 95: 471-478

Almatsier S, 2009. Prinsip Dasar IImu Gizi. Cetakan ke 7, Jakarta: Gramedia Pustaka Utama

Arisman, 2008. Gizi dalam Daur Kehidupan. Buku Ajar IImu Gizi. Buku Kedokteran. Jakarta:EGC

Depkes RI, 2014. Profil Kesehatan Indonesia. Hppt://www. Depkes.go.id

Flood Nichols, Tinnemore, Huang, Napolitano, ippolito,2015. Vitamin $D$ Deficiency in Earky Pregnancy, US National Library of Medacine National Institutes of Health

Guyton AC, 2007. Buku Ajar Fisiologi Kedokteran. Edisi 11, Jakarta: EGC

Handayani TS, 2014. Ganbaran Karakteristik Ibu dengan Kejadian Bayi Berat Lahir Rendah di RSUD Prabumuih Tahun 2014. Jurnal

Hollis, Jhonson, Hulsey, Ebeling, Wagner, 2011. Vitamin $D$ Supplement During Pregnancy:Double-Blind, Randomized Clinical Trial of Safety and Effectiveness. US National Library of Medacine National Institutes of Health

Khaleessi Nasrin, Majid Kalani, Mehdi Araghi, Zahra Farahani, 2015. The Relationship Between Maternal Vitamin D Deficiency and Low Birth Weight Neonates. Journal of Family and Reproductive Health

Mazahery $\mathrm{H}$ dan Hurst PR, 2015. Factor Affecting 25-Hydroxyviyamin $D$ Cuncotration in Respons to Vitamin D Supplementation. Nutries, 5111-5142

Nair R dan Maseeh A, 2012. Vitamin D: The "Suunshine" Vitamin. J Pharmacol Pharmacother, 118-126

Nezhard AH dan Holick M.F, 2013. Vitamin D for Health: A Global Perspective. Mayo ClinicProceendings. 720-755
Norval M dan Wulf HC, 2009. Does Chronic Suncreen Use Reduce Vitamin $D$ Production to Insufficient Levels?The British Journal of Desmatology, 732-736

Profi Kesehatan Kabupaten Tanah Datar, 20014. com

Rufaridah A. 2012. Hubungan perokok pasif terhadap plasenta, berat badan APGAR skor bayi batu lahir di kabupaten Padang Pariaman. Tesis. Fakultas Kedokteran Universitas Andalas Padang

Saifuddin, A.B ,2008. Pelayanan Kesehatan Maternal dan Neonatal. Jakarta. Bina Pustaka 